\title{
"ELIAS GEVERI OF DAMASCUS" IN RUSSIAN STUDIES OF CHURCH HISTORY: A WITNESS TO THE TWO-FINGER SIGN OF THE CROSS IN A MEDIEVAL TREATISE ON DENOMINATIONS OF SYRIAN CHRISTIANITY
}

The cultural heritage of Middle-Eastern Christianity was so influential in the rest of the Christian world that it frequently attracted the attention of scholars studying particular church traditions. It is not surprising, therefore, that Middle-Eastern Christian practices became an intriguing subject for historians of the origins of the Russian "Old Believers," a movement which itself frequently referred to some MiddleEastern Christian practices as proofs of the truthfulness of its own tradition. One such episode invoking early Middle-Eastern evidence for making the sign of the cross deserves a special inquiry.

In 1847, in the Colloquia of the Imperial Society for Russian History and Antiquities at the University of Moscow, Philaret Gumilevskiy (18051866), who was then the bishop of Riga, published his study The Worship of the Russian Church in the Pre-Mongolian Period. ${ }^{1}$ Concerning the various ways of making the sign of the cross, Bishop Philaret cited a Middle-Eastern Christian author who had touched on the subject in his treatise: "The Nestorian author Elias of Damascus who lived in the late ninth century, intending to reconcile the Syrian Monophysites with the Orthodox and the Nestorians, wrote as follows: 'As to the fact that they do not agree with each other in making the sign of the cross, this is not an obstacle at all. Some of them, for instance, make the sign of the cross with one finger and move the hand from the left side of the body to the right. Others do it with two fingers, and do so from the right side to the

(1) ФИЛАРет [ГумИлевскИй], еП. Рижский, “Богослужение Русской Церкви до монгольского времени" [Divine Service of the Russian Church before the Mongols' Time], ЧИОИДР, 7 (1847), с. 1-42. 
left... Jacobites sign themselves with one finger. By making the sign of the cross with two fingers, from right to left, Nestorians and Melkites (Orthodox) confess the faith that the divinity and the humanity < of Christ> were united while on the cross' (Assemani Bibl. Orient, T. 3, pt. 2, p. 383)." 2 This testimony was taken, as the author clearly indicated, from the famous encyclopedic work of the Maronite scholar Joseph Simon Assemani (1687-1768), the Bibliotheca orientalis, even though the reference provided was imprecise, and the other part of the Bibliotheca orientalis where Assemani had discussed this passage in more detail along with the parallel Arabic quotations, was not referenced at all. ${ }^{3}$

This testimony, introduced by bishop Philaret into Russian studies of Church history, drew both criticism and lively interest. ${ }^{4}$ In 1870, archimandrite Nikanor (Brovkovich) (1826/7-1890/1), subsequently archbishop of Kherson and Odessa, published his study, entitled The Church of St. Sophia in Constantinople: A Witness to the Ancient Orthodox Sign of the Cross. Being an expert in Latin and a polemicist, he enthusiastically translated and commented on the quotations from the treatise De concordia Fidei "by Elias of Damascus, Metropolitan of the Nestorian community," found in Assemani's Bibliotheca orientalis. ${ }^{5}$ Following Assemani's account, Nikanor wrote, "Who was this Elias of Damascus? ...Elias ...nicknamed Geveri (Гевери), the Nestorian bishop of Jerusalem, was ordained metropolitan of Damascus by the patriarch John on the 15th of July of the year 1204 of the Greek era (i.e. since Alexander the Great), <corresponding to the year $>893$ of the Christian

(2) Филарет, еп. Рижский, “Богослужение Русской Церкви”, с. 31, n. 2. Italics in the original.

(3) The correct reference is: t. 3, pt. 2, 388 and t. 3, pt. 1, pp. 513-516.

(4) The critics regarded the testimony as an argument in favour of the Old Believers. See Letter 84 (especially its postscript) in Письмa Фuлареma, Aрхиепископа Черниговского, к А. В. Горскому [Letters of Philaret, Archbishop of Chernigov, to A. V. Gorsky], Москва, 1885, с. 216-217; Е. Голуьинский, "К нашей полемике с старообрядцами" [Concerning Our Polemics with the Old Believers], ЧИОИДР, 3/214 (1905), с. 246.

(5) НикАнор [Бровкович], архим., “Цареградская церковь святой Софии - свидетельница древле-православного перстосложения" [Constantinople's church of Saint Sophia - the witness of the Old Orthodox arrangement of fingers], Православный собеседник, издаваемьй при Казанской Духовной Академии, 3 (1870), с. 189-202. Nikanor's reference, like that of bishop Philaret, is to the second part of the third volume of the Bibliotheca orientalis, but he adds another reference - to the more detailed description of the treatise in the first part of the third volume of the Bibliotheca orientalis. 
era..." ${ }^{\prime 6}$ Thus, owing to archimandrite Nikanor, "Elias Geveri" (И^iя Гевери) became a reality in Russian studies of Church history. ${ }^{7}$

N. Th. Kapterev (1847-1918) further developed the testimony and wrote the following in his study The Patriarch Nikon as a Reformer of the Church and His Opponents, published in 1887 in the Orthodox Review: "This very important witness to making the sign of the cross with two fingers by the Greeks $<$ sic! - N. S. $>$ is provided by the Nestorian metropolitan Elias Geveri, who lived in the late ninth and early tenth century." ${ }^{8}$ He corrected the reference supplied by bishop Philaret, but nevertheless overlooked the more detailed account of the treatise $D e$ concordia Fidei provided by Assemani in the first part of the third volume of his Bibliotheca orientalis.

In the eighth volume of his History of the Russian Church that appeared in 1877, ${ }^{9}$ Makary Bulgakov, the metropolitan of Moscow and Kolomna (1816-1882), wrote that "Elias Geveri, the Nestorian metropolitan of Damascus (since AD 893), previously the Nestorian bishop of Jerusalem, argued in his treatise that all three Christian divisions or communities in Syria - the Jacobites, the Nestorians, and the Melkites - allegedly agree with each other in matters of faith and are at variance only in the ways in which they express their faith." Thereafter, he reproduced the aforementioned testimony concerning the ways of making the sign of the cross. ${ }^{10}$

(6) Никанор, архим., “Цареградская церковь святой Софии,” с. 190. Italics in the original.

(7) Archimandrite Nikanor's study was reprinted as part of his book О перстосложении дяя крестного знамения и благословения. Беседа Никанора, Aрхиепископа Херсонского и Одесского [Concerning the Arrangement of Fingers forMaking Sign of the Cross and Blessing], Санкт-Петербург, 1890.

(8) Н. Ф. КАПтЕРЕВ, “Патриарх Никон как церковный реформатор и его противники" [The Patriarch Nikon as a Reformer of the Church and His Opponents], Православное обозрение, 1 (1887), с. 348.

(9) “Жизнеописание Высокопреосвященного Макария, Митроподита Московского и Коломенского" [Biography of Most Eminent Makarius, Metropolitan of Moscow and Kolomna], in Макарий (БулгАКов), Митрополит Московский и Коломенский, История Русской Церкви [History of the Russian Church], кн. 1, Москва, 1994, с. 29.

(10) История Русской Церкви Макария, Архиепископа Литовского и Виленского [History of the Russian Church by Makarius, Archbishop of Lithuania and Wilno], кн. 3, т. 8, Санкт-Петербург, 1877, с. 103-104. The reference here is again to the second part of the third volume of the Bibliotheca orientalis. After 
We find the usual references to "the Nestorian metropolitan Elias Geveri" and to his account of the various ways of making the sign of the cross also in the studies of other distinguished Russian historians of the Church, such as P. S. Smirnov (1861-after 1917) ${ }^{11}$ and E. E. Golubinskiy (1834-1912), ${ }^{12}$ who referred to bishop Philaret's The Worship of the Russian Church in the Pre-Mongolian Period, as well as in more recent research carried out by Russian scholars. ${ }^{13}$

Let me now focus on the original Middle-Eastern source containing the testimony, so significant for all those studying Russian Christianity and especially the Old Believers movement, which always insisted that the two-finger sign of the cross is a crucially important token of their faith.

The Book of the Concordance of Faith (Kitāb iğtimā' al-amāna) is extant in the following two recensions:

(1) the recension of the Bodleian Library manuscript (16th century; MS Ar. Uri 38 / Huntington 240; fol. 119v-124v), which was published by Gérard Troupeau in $1969 .{ }^{14}$ It was written, as the editor remarks, in an oriental Egyptian Arabic script ("écriture orientale (Égypte)"). ${ }^{15}$

(2) the recension of the Vatican Library manuscript, dating to AD 1692 (1103 Anno Hegirae, 2003 Anno Graecorum) - Vat. ar. 657, fol. $4 v-15 r .{ }^{16}$ This second recension was described and presented in

that, the correct pages of the first part of the volume are given, but the part of the volume still remains unspecified.

(11) П. Смирнов, “О перстосложении для крестного знамения и благословения" [Concerning the arrangement of fingers for making sign of the cross and blessing], XY, 2 (1904), c. 219-220.

(12) Е. Голуьинский, “К нашей полемике с старообрядцами,” с. 158.

(13) See, for example, Б. А. Успенский, Крестное знамение и сакральное пространство: Почему православные крестятся справа налево, а католики слева направо? [Sign of the Cross and Sacred Space: Why Orthodox Make the Sign of the Cross from the Right to the Left, and the Catholics - from the Left to the Right], Москва, 2004, с. 61 (сн. 16-17), 65-66 (сн. 23).

(14) G. Troupeau, "Le livre de l'unanimité de la foi de 'Alī ibn Dāwud al-Arfādī," Melto, 5:2 (1969), pp. 197-219; repr. in G. Troupeau, Études sur le christianisme arabe au Moyen Âge, (Variorum Collected Studies Series, CS515) Aldershot; Brookfield, 1995, no. XIII, pp. 201-219.

(15) Troupeau, “Le livre de l'unanimité de la foi,” p. 197, n. 1.

(16) For the description of the manuscript, see A. MAI, Scriptorum veterum nova collectio e Vaticanis codicibus edita, t. 1-10, Romae, 1825-1838, t. 4 (1831), p. 583 (No. DCLVII / A.53). 
excerpts by Assemani in his Bibliotheca orientalis. ${ }^{17}$ The Vatican manuscript contains the text of the The Book of the Concordance of Faith written in Garshūnī, i.e. in Arabic transcribed into Syriac script (Eastern Syriac script, in this case).$^{18}$ The present author has recently published a critical edition of the Garshūnī recension. ${ }^{19}$

The first part of the third volume of the Bibliotheca orientalis ("De Scriptoribus Syris Nestorianis") presents The Book of the Concordance of Faith as a treatise by "Elias the Nestorian metropolitan of Jerusalem and Damascus," ("Elias Hierosolymæ \& Damasci Nestorianorum Metropolita"). In this section, Assemani presented some excerpts from the treatise ${ }^{20}$ re-transcribed into the Arabic script. While doing the reversed transcription, he introduced some changes in the text. One can assume that these changes were triggered by his discomfort with the East-Syriac script of the manuscript as well as with some elements of the Iraqi

(17) J. S. Assemani, Bibliotheca Orientalis Clementino-Vaticana, t. 1-3, Romae, 1719-1728, t. 3:1 (1725), pp. 513-516.

(18) Д. А. Морозов, “Каршӯнй: сирийская письменность в арабохристианских текстах" [Karšūnī: Syriac script in Christian Arabic texts], in Пятые чтения памяти профессора Николая Федоровича Каптерева. Россия и православный восток: новые исследования по материалал из архивов и музейных собраний. Москва, 30-31 октября 2007 2. Mатериаль [Fifth Conference in the Memory of Professor Nikolai Kapterev. Russia and Orthodox East: New Research of Materials from Archives and Museum Collections. Moscow, October 30-31, 2007. Materials], Москва, 2007, с. 70-72. See also his important forthcoming article "Каршуни" (Кагšūnī), in Православная Энц̧иклопедия [Orthodox Encyclopedia]; A. Mingana, "Garshūni or Karshūni?" Journal of the Royal Asiatic Society (1928), pp. 891-893; F. BRiquel-ChAtonnet, "De l'intérêt de l'étude du garshouni et des manuscrits écrits selon ce système," in L'Orient chrétien dans l'empire musulman: Hommage au professeur Gérard Troupeau (Studia arabica, III), Versailles, 2005, pp. 463-475. For specific characteristics of the Eastern ("Chaldean") Garshūnī see H. RAM, Qișsat Mâr Êlî̌âa (Die Legende vom Hl. Elias). Als Beitrag zur Kenntnis der arabischen Vulgär-Dialekte Mesopotamiens nach der Handschrift Kod. Sachau 15 der Königl. Bibliothek zu Berlin herausgegeben, übersetzt und mit einer Schriftlehre versehen, Inaugural-Dissertation, Leipzig, 1906.

(19) Н. Н. СЕлезнев, “Западносирийский книжник из Арфа̄да и иерусалимский митрополит Церкви Востока. «Книга общности веры» и ее рукописная редакция на каршуни" [A West-Syrian Bookman from Arfād and the East-Syriac Metropolitan of Jerusalem. "The Book of the Concordance of Faith" and Its Manuscript Recension in Garshūnī], Cuм вол 58: Syriaca $\mathcal{E}$ Arabica (2010), c. 34-87, 45-72 (text in Garshūnī), c. 73-87 (Russian translation).

(20) Fol. 4v:4, fol. 4v:10, fol. 7r:17-7v:12, fol. 13v:11-14r:2, fol. 10v:410v:10, fol. 10v:10-11r:16, fol. 11r:16-12r:5, fol. 12v:2-12v:17. 
dialect ${ }^{21}$ which had crept into the text. Both were equally unfamiliar to the Maronite author whose own dialect was Lebanese, and whose usual Syriac script was the West-Syriac serțo. The Vatican manuscript has a note in the introduction (fol. 4[v]:2), saying that Elias al-Ǧawharī, the metropolitan of Jerusalem, re-wrote or copied (nasaha-hu) the treatise that follows. Assemani latinized "al-Ğawharī" (i.e. "the Jeweller," probably a reference to the family business) as Geveri, a possible Italian transcription of the name. Afterwards, archimandrite Nikanor phonetically transcribed this word into Cyrillic as Гевери, according to the normal for Russian scholars German or Polish-like pronunciation of Latin words. In this form - Гевери - the name was adopted into Russian scholarly literature. Assemani's attribution of the Book of the Concordance of Faith to "Elias Geveri, the Nestorian metropolitan" was uncritically taken over by bishop Philaret and subsequent Russian historians. Neither Assemani nor later scholars discussing the subject took notice of the the Garshūnī version's indication that it was merely copied (rather than composed) by Elias al-Ğawharī.

In the text of the Bodleian Library the treatise is attributed to 'Ali ibn Dāwūd al-Arfādī. It is worth mentioning that in his catalogue of the Bodleian Library Joannes Uri (1726-1796) omitted the reference to the Book of the Concordance of Faith as part of the manuscript Ar. Uri 38 / Huntington 240.22 Presumably because of this, neither did Georg Graf (1875-1955) mention 'Al̄i ibn Dāwūd al-Arfādī as the author of the Book of the Concordance of Faith in his monumental Geschichte der christlichen arabischen Literatur, but, following Assemani, placed the treatise in the section on "Elias (Ilīyā) al-Ğawhari von Jerusalem und Elias von Damaskus." 23

An Arabic-speaking medieval Coptic author Mu'taman (ad-Dawla) ibn al- 'Assāl (13th century) ${ }^{24}$ prepared a synopsis of the Book of the Concordance of Faith in the eighth chapter of his Summa of the Foundations of Religion and of the Traditions (lit. What was Heard) of Reliable Knowl-

(21) E.g., fol. [4]v:4 and fol. 12v:13-15.

(22) J. URI, Bibliothecæ Bodleianæ codicum manuscriptorum orientalium, videlicet Hebraicorum, Chaldaicorum, Syriacorum, Æthiopicorum, Arabicorum, Persicorum, Turcicorum, Copticorumque catalogus. Pars prima, Oxonii, 1787 [Ar. Chr.], p. 34.

(23) G. Graf, Geschichte der christlichen arabischen Literatur, Bd. 1-5 (ST, 133), Città del Vaticano, 1944-1953, Bd. 2, S. 132-133.

(24) About him see Graf, Geschichte der christlichen arabischen Literatur, Bd. 2, S. 407-414. 
edge (Mağmū' ușūl ad-dìn wa-masmū' mahșūl al-yaqinn). In the subtitle he gave to the section, he indicates that he reproduces a treatise of "Elias, the metropolitan of Jerusalem, on the same subject, entitled $<$ The Book $>$ of the Concordance of Faith and the Brief Exposition of Religion, and it is $<$ also > said that this <treatise > is <by> 'Alī ibn Dāwūd." ${ }^{25}$ Ibn al- 'Assāl, evidently, was aware of both attributions, and he duly provides both in mentioning the author of the Book of the Concordance of Faith. While exploring the Summa of the Foundations of Religion in the Vatican and Paris manuscripts (Vat. ar. 103, fol. 91v-94 and Paris, BNF ar. 200, fol. 63-65v), Gérard Troupeau misinterpreted this double ascription as a claim that Elias of Jerusalem was indentical with 'Alī ibn Dāwūd and remarked that he found this alleged identification (in actual fact, never made by Ibn al- 'Assāl) rather improbable. ${ }^{26}$

Concerning 'Al̄̄ ibn Dāwūd al-Arfādī, Troupeau indicates that he is "completely unknown in the history of Christian Arabic literature" ("totalement inconnu dans l'histoire de la littérature arabe chrétienne") and surmises that he was a Syrian, since the village Arfād which provided 'Alī ibn Dāwūd with his nisba (a name indicating the place of origin) was located, according to the geographical dictionary of Yāqūt al-Hamawī (1179-1229), near 'Azāz north of Aleppo. ${ }^{27}$ Sidney H. Griffith could not find any definite information about alArfādī, either, and consequently characterized the author as "the shadowy 'Alī ibn Dāwud al-Arfādī, of uncertain date and denomination." 28 Troupeau suggests that the author of the Book of the Concordance of Faith belonged to the West-Syriac ("Jacobite") community on the ground of his analysis of the contents of the treatise: al-Arfādī's accounts of the "Nestorians" and the "Melkites" are rather brief, whereas his descriptions of the views of the "Jacobites" are more detailed and are placed at the end of each comparative section. Moreover, he characteristically emphasizes the significance of the "oneness of Christ." 29 Troupeau also

(25) A. WAdi [= W. Abullif], B. PIrone, "al-Mu’taman Abū Isḥāq Ibrāhīm Ibn al- 'Assāl," Mağmū' ușūl al-dīn wa-masmū ' mahșūul al-yaqīn. Summa dei principi della Religione (SOC; Monographiae, 6a-9), Cairo, Jerusalem, 1998, vol. 1, SOC, 6a, pp. 187-192.

(26) Troupeau, 1969, p. 198.

(27) Ibid.

(28) S. H. Grifrith, Church in the Shadow of the Mosque: Christians and Muslims in the World of Islam, Princeton, Oxford, 2008, p. 142.

(29) Troupeau, 1969, p. 199. 
argued for the eleventh century as the probable period of al-Arfādī's life and floruit, but did not furnish any substantial evidence in support of this suggestion. He further remarks that al-Arfādī was probably the author of another treatise - On the Verity of the Gospel (Kitäb fì sihhat al-Inğil) - referenced by the author himself in the section of the Book of the Concordance of Faith discussing the Gospels. ${ }^{30}$

Assemani suggested to identify Elias al-Ğawharī with Elias ibn 'Ubayd who first occupied the episcopal see of the Church of the East in Jerusalem and was then elevated to the metropolitan see of the same Church in Damascus. ${ }^{31}$ This identification was based on 'Amr ibn Mattā's report about the patriarch of the Church of the East John (Yuwānīs) who "in the middle of Tammūz $<$ July $>$ of the year 280 of the Hiğra, i.e. the year 1204 of the Seleucid era $<$ AD $893><$... $>$ on the day of his own ordination, ordained Elias ibn 'Ubayd, the bishop of Jerusalem, as the metropolitan of Damascus." ${ }^{22}$ The suggested identification would become impossible if we assume that al-Arfādi lived in the eleventh century, as suggested by Troupeau, along with the additional witness of the Vat. ar. 657, according to which Elias al-Ğawharī only "copied" the Book of the Concordance of Faith. It should also be noted that Troupeau's suggestion was based on his evaluation of the Bodleian Library text, which had undoubtedly undergone a later editing; hence, Troupeau's conclusion can be subject to revision. It may be added to our survey that "Elias, the bishop of Jerusalem" is also known as the author of the Book of Casting Away the Sorrows (Kitāb fi tasliyat al-ahzzān) published by the Italian orientalist Giorgio della Vida (1886-1967), ${ }^{33}$

(30) Troupeau, 1969, p. 199.

(31) Assemani, Bibliotheca Orientalis, t. 3:1, p. 513; See also Graf, Geschichte der christlichen arabischen Literatur, Bd. 2, S. 132.

(32) H. Gismond, Maris, Amri et Slibae de patriarchis Nestorianorum commentaria / Ex codicibus Vaticanis edidit ac latine reddidit Henricus Gismondi, Romae, 1896-1899, pars II, pp. 80-81 (Ar. text), pp. 46-47 (Lat. tr.); В. В. Болотов, Из истории Церкви сиро-персидской [From the History of the Syro-Persian Church], Санкт-Петербург, 1901, с. 120/1190.

(33) G. Troupeau, Catalogue des manuscrits arabes. Première partie: manuscrits chrétiens. Tt. 1-2, Paris, 1972-1974, t. I, 176 (N 206:1); G. Levi Della VIDA, "Il conforto delle tristezze di Elia al-Ğawhari (Vat. ar. 1492)," in Mélanges Eugène Tisserant (ST, 232), Città del Vaticano, 1964, vol. 2: Orient chrétien, pt. 1, pp. 345-397. 
and that Assemani also attributed a Nomocanon Arabicus to "Elias Geveri." 34

Troupeau characterized the Vatican recension as being an abridged one ("une recension abrégée"), ${ }^{35}$ but in actuality the problem of the relationship between the two manuscripts containing the treatise in question is more complex. First of all, the Vat. ar. 657 witnesses to evident omissions in the text of the Bodleian Library manuscript, despite the fact that the latter recension was characterized by Troupeau as "complete" ("une recension complète") $)^{36}$ - for example Vat. ar. 657, fol. 8v:13-15 and Vat. ar. 657, fol. 9r:1 are lacking in the Bodleian Library manuscript. Second, it is obvious that the Bodleian library text, in comparison to that of the Vatican, looks stylistically edited. Thus, the literary particle qad is more frequently used in the Bodleian Library text than in the Vatican text. ${ }^{37}$ Since one can hardly imagine that these particles would be systematically removed for the sake of "abridgement," it stands to reason that the Bodleian Library text added the particles to improve the style. It should be noted that a very similar sort of editing is evident in yet another treatise that the same Bodleian Library manuscript contains: The Treatise on the Union by Ibn at-Tayyib (fol. 104r-105r), when it is compared with the other recension of the work (Vat. ar. 145 , fol. $67 \mathrm{v}-71 \mathrm{v}$ ). ${ }^{38}$

When compared with the two manuscripts mentioned above, the synopsis made by Mu'taman ibn al-'Assāl presents readings characteristic of the same branch of the manuscript tradition of the Book of the Concordance of Faith to which the text of the Bodleian Library belongs. It is curious, however, that the Coptic encyclopedist omitted the paragraph devoted to the various ways of making the sign of the cross. Only towards the end of his synopsis, Ibn al- 'Assāl remarks that "the Jacobites made the sign of the cross from the left side to the right, and the others made it in the opposite way." He explains that he "did

(34) Assemani, Bibliotheca Orientalis, t. 3:1, pp. 513-514. See also Graf, Geschichte der christlichen arabischen Literatur, Bd. 2, S. 133-134.

(35) Troupeau, 1969, 198.

(36) Ibid., p. 197.

(37) Cf. Vat. ar. 657, fol. 5r:15, fol. 7v:16-17, fol. 8v:1, fol. 10r:11, fol. 13r:5.

(38) See various readings indicated in G. Troupeau, “Le traité sur l’Union de 'Abd Allāh ibn al-Ṭayyib," Parole de l'Orient, 8 (1977-1978), 141-150; repr. in: G. Troupeau, Études sur le christianisme arabe au Moyen Âge, Essay VII. The Vatican version of this text was also alleged to have numerous omissions, but in actuality has no evident textual defect. 
not indicate this because it was widely known and because both ways were equally acceptable, and the subject was trivial." ${ }^{39}$

In conclusion, let us consider again the role of bishop Philaret in introducing the Middle-Eastern Christian material to Russian historical studies. What was his motivation in exploring Assemani's Bibliotheca orientalis and digging out the testimony of a virtually unknown Syrian author to the early practice of a two-finger sign of the cross, even though this was to subject him to much criticism?

His interest in the Christian Orient was not accidental. Thus, for instance, in his letters he is known to have valued the heritage of Syriac Christianity so highly that he became suspicious of Slavonic translations made from Greek. Thus, in his letter to the archpriest Alexander V. Gorskiy (1812-1875) ${ }^{40}$ dated December 14, 1852, he wrote: "The Fathers of the Church, especially St. Ephrem the Syrian, are truthful guides. By the way, when will St. Ephrem's Commentaries on the Holy Scripture be translated <into Russian>? I so much wish I could see then in a Russian translation!" 41 In his letter of February 4, 1853, he wrote: "The works of St. Ephrem are my favourite hymns, his commentaries are jewels! Were you embarrassed by the discrepancy between the Slavonic and the Syriac texts? Did you try to reconcile them <in your translation>? It is pitiful, if you changed the meaning of the Syriac text just to make it conform to the abomination of the printed Slavonic <translations> ("чтобы только согласить его съ безобразіемъ печатной славянщины"). ${ }^{42}$ It is therefore not surprising to find a Russian translation of the Testament of St. Ephrem made from Syriac in the list of bishop Philaret's publications. ${ }^{43}$ In his introduction to this transla-

(39) Wadi-Pirone, Mağmū' ușūl al-dīn wa-masmū ' mahṣūul al-yaqīn, vol. 1, SOC, 6a, 192.

(40) Геннадий (Гоголев), архим., С. В. Рижский, А. А. Турилов, “Горский Александр Васильевич," in Православная Эничиллопедя [Orthodox Encyclopedia], Т. XII, Москва, 2006, с. 149-152.

(41) Письма Филарета, Архиепископа Черниговского, к А. В. Горскому, с. 268. It was Aleksandr Kirillovich Sokolov (1818-1884) who was responsible for the translations of St. Ephrem's works from Syriac. He worked at the Moscow Theological Academy. About him see Д. Д. Языков, Обзор жизни и трудов покойных русских писателей [A Survey of Lives and Works of the Late Russian Writers], вып. 4, Санкт-Петербург, 1888, с. 81.

(42) Ibid., c. 270.

(43) Русские писатели-богословы: историки Церкви, исследователи и толкователи Священного Писания. Биобиблиографический указатель [Russian 
tion, he remarks: "The translation from the Greek version was published in the Christian Reading (27/1827). If the reader wishes to see the advantage of the original <i.e. Syriac $>$ text, he should only compare the initial lines of the translation presented here with the translation published in the Christian Reading. The author of the Greek version, wishing to make it clearer, made additions and alterations, sometimes very unfortunate." ${ }^{44}$ Bishop Philaret's special interest in Syriac literature is also evident in his three-volume Historical Studies of the Fathers of the Church. ${ }^{45}$ In view of the foregoing discussion, one can conclude that the scholarly circle of bishop Philaret and archpriest Alexander V. Gorskiy, who worked at the Moscow Theological Academy, was an important point in the development of Syriac studies in Moscow. ${ }^{46}$

The introduction of the Book of the Concordance of Faith, which also provides a useful summary of the treatise, and the chapter discussing the various ways of making the sign of the cross are presented below in an English translation prepared by Nikolai N. Seleznyov in consultation with Dmitry A. Morozov.

Theologians: Church Historians and Biblical Scholars]. 2nd ed., Москва, 2001, с. 171. In his letter of May 5, 1843, bishop Philaret wrote concerning his work on the translation of the "Syriac Ephrem." See Письма Филарета, с. 119. In the same letter, he mentioned "Hoffmann's Syriac Grammar" [i.e. Andreae Theophili Hoffmanni... Grammaticae Syriacae Libri III, Halae, 1827], to which he probably owed his knowledge of Syriac (Ibid.).

(44) ФИлАРЕт, архиеп., “Завещание Св. Ефрема” [The Testament of St. Ephrem], Черниговские епархиальные известия. Прибавления, 1 (март, 1862), c. 1, n. 1 .

(45) ФИЛАРЕТ, архиеп. Черниговский и Нежинский, Историческое учение об отцах Церкви [Historical Research on Church Fathers], t. 1-3, СанктПетербург, 1859.

(46) Syriac studies in Moscow probably began with the famous Lutheran pastor Johann Ernst Glück (1652-1705) who opened his school there in 1703. The pastor's son Christian Bernard Glück was appointed to teach Syriac as well as Hebrew, Chaldean, and Greek. See Н. И. Веселовский, “Сведения об официальном преподавании восточных языков в России" [Information on Teaching Oriental Languages in Russia in the Official Institutions], in Tpyды третьего международного съезда ориенталистов в С.-Петербурге $1876=$ Travaux de la troisième session du Congrès international des orientalistes. St.-Pétersbourg 1876, t. 1, Санкт-Петербург, 1879-1880, с. 208. 


\section{INTRODUCTION}

(Vat. ar. 657, fol. 4v:1-6v:7)

In the name of God, the Merciful, the Compassionate, from Whom we seek help. We <begin> transcribing the book which was copied by the learned, respectable holy father, pure, worthy, spiritual Mār Elias of the Lord, al-Ğawharī, the metropolitan of the noble Jerusalem (al$Q u d s)$, the earthly throne of God, pastor of pastors of Christians and leader of those washed clean with the water of baptism, may his prayer embrace us and all the faithful. Amen.

This ${ }^{47}$ book is about the concordance of faith, the origin of religion, and the pride of orthodoxy ${ }^{48}$ (of the Syrians named Nestorians, Melkites, and Jacobites; a treatise of saint Mār Elias, may God sanctify his pure spirit and have mercy upon us according to his prayer. Amen. $)^{49}$

(Mār Elias) $)^{50}$ said: $\mathbf{1}^{51}$. When I looked at the magnificence of the Christian faith $^{52}<$ from the point of view of $>$ the truthfulness of the faith in God - Who is Great and Glorious! - ${ }^{53}$ the appropriately celebrated services ${ }^{54}$ to the Creator of (heaven) $)^{55}$ and earth, and of what is upon (it), ${ }^{56} 57$ according to the law of guidance commanded by the Merciful Creator, ${ }^{58}$ propagated ${ }^{59}$ throughout the Orients of the earth and its Occidents, ${ }^{60}$ among the peoples and nationalities scattered over remote countries and all the lands, < while> every nation among them

(47) Absent (abs.) in Troupeau's edition (T).

(48) T added (add.): glorious.

(49) T:abs.

(50) T: 'Alī ibn Dāwūd al-Arfādī, prosperous in God and a slave of obedience to Him.

(51) Paragraph numbers follow Troupeau's edition.

(52) T add.: and found it brilliant.

(53) T add.: pure faith.

(54) T add.: proper.

(55) T: heavens.

(56) In the MS used by Troupeau: in them [i.e. in the heavens].

(57) T add.: ornated with beloved knowledge.

(58) T add.: rich.

(59) T: being spread.

(60) T add.: and its remotest, and its nearest, manifestly, abundantly. 
is proud of what it has of the Christian religion, ${ }^{61}$ common for all (upon the earth) ${ }^{62}$ and of $<$ its own $>$ confession, ${ }^{63}$ then I saw that a situation inspired by the devil ${ }^{64}$ overtook some $<$ of $>$ these peoples, and consequently, there happened a divergence ${ }^{65}$ of some of them from the others following the way of passion (opposed to the mind) ${ }^{66}$ and so they split into many divisions of which one could speak for long. But even if they do, all their multiplicity aside, agree ${ }^{67}$ in opinions and differ from each other in passions, they are reducible to three divisions (firaq), for they ascend to three denominations (madāhib) as their roots, ${ }^{68}$ namely (the division of the Nestorians, the division of the Melkites, and the division of the Jacobites); everything that exists apart from these three communities (al-milal) ${ }^{69}$ are $<$ in fact $>$ divisions which (originate) $)^{70}$ from them and are reducible to them, as are the Maronites, the Isaacians, and the Paulinians, ${ }^{71}$ and other <divisions $>$ of the Christian religion apart from them. I found that every one of these three aforementioned communities has $<$ its own $>$ ignoramuses, and every $<$ community $>$ has its own troublemakers and squabblers, and that every community ${ }^{72}$ defames those who contradicts it $<$ s position $>$, accusing them of disbelief, impiety, and departure from the faith, and they curse the <supposed $>$ disbelief of each other.

(61) T add.: and rejoice at what it has.

(62) T abs.

(63) T add.: in the truthful Gospel which is the principle of religion, and a part of faith, and the light of truth.

In the synopsis of Mu'taman ibn al-'Assāl: in the Gospel, the truthfulness of which is strong.

(64) T add.: cursed.

(65) T add.: and mutual disagreement.

(66) T: which passes [limits] the minds / which infects minds.

(67) T: mutually part with [each other]; Troupeau translates in French: "elles s'écartent."

(68) T add.: and they are an offshoot of them.

(69) T add:: besides these.

(70) $\mathrm{T}$ : because they take/originate from them.

(71) This is the reading of T; the Garshūnī text reads: al-qawlāniyya.

(72) In the MS used by Troupeau: people. 
When I thoroughly considered this and examined it as it should be examined, ${ }^{73}$ I found no difference between them which would entail contradictions in what concerns the religion and the faith and saw no $<$ situation> among them where someone's faith would refute someone else's, and someone's views would deny another's views, 2. (but they all $)^{74}$ come together in their faith and in the principles of their preaching to the (pure Gospel) ${ }^{75}$ which (God sent down) ${ }^{76}$ and which the leaders of the truthful way - the righteous apostles, i.e. the disciples of our Lord Jesus Christ - passed on to them. (I found no one who would disagree with anyone else in his testimony to the truthful Gospel, $<$ for there is $>$ no one $)^{77}$ who adds <anything to it> or takes anything away $<$ from it $>$, but they all read (the Holy Gospel, the Epistles ${ }^{78}$ of Paul) ${ }^{79}$ our Lord's and (Saviour's) ${ }^{80}$ apostle, which are fourteen epistles that prove the Gospel, (and also the Book of Acts), ${ }^{81}$ and they all agree in accepting this and assert ${ }^{82}$ the truthfulness of this. And since the Gospel is the principle of religion, and <the Book of the Epistles of $>$ Paul is its proof, and the $<$ Book of the $>$ Acts is a witness to it, then there is $\mathrm{no}^{83}$ difference between them, nor any contradiction, for their faith is right in $<$ what is considered to be right in $>$ religion.

(73) T: metathesis looked through the pages as it should be looked through the pages.

(74) T: because they.

(75) T: the truthful Gospel of God.

(76) Tabs.

(77) $\mathrm{T}$ : When looked through the pages of what these three communities had from the Gospel, I did not find in what they have anything concerning which anyone would disagree with any other.

(78) Tabs.

(79) In the synopsis of Mu'taman ibn al- Assāl: the Gospel and the apostles' sayings.

(80) T abs.

(81) T: When I considered this, I found in it no disagreement with any other community, either [by way of] addition, or [by way of] taking away. I also examined the Book of Acts and that of the epistle [of Paul] and the catholic [epistles] of the disciples of Christ our Lord, and while comparing them with each other I found neither any addition to what others have, nor any taking away from it.

(82) T: obey.

(83) T: I did not find. 


\section{On the Sign of the Cross}

(Vat. ar. 657, fol.10v:10b-11r:16a)

7. Concerning their divergence in making <the sign of $>$ the cross, ${ }^{84}$ some of them make $<$ the sign of $>$ the cross with (one finger) ${ }^{85}$ beginning from (the left side <and going > to the right, while others do it with two fingers, beginning from the right side <and going $>$ to the left). ${ }^{86}$ This circumstance does not ${ }^{87}$ imply any division, but is of the same kind ${ }^{88}$ as what I wrote on $<$ the subject of $>$ one nature versus two natures, because the Jacobites make $<$ the sign of $>$ the cross with one finger, beginning from the left side < and going $>$ to the right, thus pointing to (the faith in the one Christ who, while on) ${ }^{89}$ the Cross, saved them by his crucifixion <and led them $>$ from the left side, which is the $<$ side of $>\sin$, to the right side, which is the $<$ side of $>$ forgiveness. Then, when the Nestorians and the Melkites make <the sign of the cross> with two fingers, beginning from the right side <and going $>$ to the left, they mean ${ }^{90}$ that the divinity and the humanity <of Christ $>$ were together on the Cross, (because the salvation <was achieved $>$ through this, and $<$ consequently $>$ there appeared $)^{91}$ faith from the right side, ${ }^{92}$ and disbelief was banished from the left side, ${ }^{93}$ which is delusion. This is a subject in which there is no difference that would necessarily make

(84) T: sign (išāra) of the cross; in the synopsis of Mu'taman ibn al- 'Assāl: sign ( $\mathrm{rašm})$ of the cross.

(85) T: two fingers.

(86) T: the right side [and goes] to the left side, and someone from them does it with one finger and begins from the left side [and goes] to the right side.

(87) T: contradiction.

(88) Following the reading of Troupeau's edition.

(89) These words are absent from the manuscript on which Troupeau's edition is, but are present in his edition. Most likely, they were lifted from the fragment of the Vatican text reproduced in Assemani's Bibliotheca orientalis, though Troupeau makes no reference to it.

(90) In the Garshūn̄̄ manuscript: faith [then crossed out:] thus from the right side.

(91) T: without division, and that the salvation was manifested.

(92) T add.: which is the right way.

(93) T: to the side. 
a violator ${ }^{94}<$ of any particular custom $>$ impious, because the meaning ${ }^{95}$ of the faith is one.

\section{SUMMARY}

In studies of the history of the Old Believers movement, written by Russian historians, one frequently comes across references to the medieval treatise by "Elias Geveri, the Nestorian Metropolitan," that contains a testimony to the two-finger sign of the cross current in his time among the Melkites. The treatise is known in two recensions, only one of which belongs to "Elias Geveri" (i.e. al-Ğawharī), while the other, probably the original one, is attributed to 'Alī ibn Dāwūd al-Arfādī. This article offers a critical study of the source on which these references are based and surveys its textual history with a view to defining its role in Russian studies of Church history.

(94) T: contradicting him.

(95) The reading of Troupeau's edition. 